\title{
Dry season distribution of land crabs, Gecarcinus quadratus (Crustacea: Gecarcinidae), in Corcovado National Park, Costa Rica
}

\author{
Megan E. Griffiths ${ }^{1,2}$, Basma A. Mohammad ${ }^{1,3}$ \& Andres Vega ${ }^{4}$ \\ 1 Department of Biology, Tufts University, Medford, MA 02155, USA \\ 2 Present Address: Forest Biodiversity Research Unit, School of Biological and Conservation Sciences, University of \\ KwaZulu-Natal, Private Bag X01, Scottsville 3209, Pietermaritzburg, South Africa; Griffithsme@ukzn.ac.za \\ 3 Monterey Institute of International Studies, Monterey, CA 93940, USA. \\ 4 Ambiente, Biología, e Investigación en Corcovado, Estación Biológica Sirena, Parque Nacional Corcovado, Costa Rica
}

Received 12-VII-2004. Corrected 19-VII-2006. Accepted 15-XII-2006.

\begin{abstract}
The land crab Gecarcinus quadratus is an engineering species that controls nutrient cycling in tropical forests. Factors regulating their coastal distribution are not fully understood. We quantified land crab distribution during the dry season at Sirena Field Station in Corcovado National Park, Costa Rica, and found that land crab burrow density decreases with increasing distance from the ocean. Leaf litter depth and tree seedling density are negatively correlated with land crab burrow density. Burrows are strongly associated with sand substrate and burrow density is comparatively low in clay substrate. Results suggest that G. quadratus is limited to a narrow coastal zone with sand substrate, and this distribution could have profound effects on plant community structure. Rev. Biol. Trop. 55 (1): 219-224. Epub 2007 March. 31.
\end{abstract}

Key words: burrow counts, Corcovado National Park, Costa Rica, Gecarcinus quadratus, Gecarcinus lateralis, land crabs, leaf litter.

Recent studies have called attention to the influence that land crabs have on coastal ecosystems (Green et al. 1999, Sherman 2002, 2003). Gecarcinus quadratus, G. planatus and Gecarcoidea natalis process large quantities of leaf litter, thereby influencing nutrient cycling (O'Dowd and Lake 1991, Kellman and Delfosse 1993, Sherman 2003). Land crabs alter the structure of plant communities through selective consumption of seeds and seedlings (García-Franco et al. 1991, Jiménez et al. 1994, Sherman 2002). In addition, their burrows provide habitat for obligatory and facultative arthropod symbionts (Bright and Hogue 1972). Based on the direct and indirect influences of these species on resource availability, as well as their modification of habitat, land crabs can be considered allogenic ecosystem engineers (Jones et al. 1994, Green et al. 1997).
While previous studies have described the ranges of land crab populations on islands (Bliss 1968, Wolcott and Wolcott 1982, 1988, Wolcott 1992, Green et al. 1997), few published studies have quantitatively described the distribution of land crabs in mainland populations. With the exception of Sherman (1997, 2002, 2003), there has been limited research on Gecarcinus lateralis and G. quadratus populations inhabiting the Pacific coasts of Central and South America. Because these species are ecologically important in tropical forest ecosystems, it is critical to understand both their local distributions and the factors that influence these distributions.

Corcovado National Park supports populations of the land crab G. quadratus. Sherman $(1997,2002)$ found that G. quadratus occurred in coastal areas of Corcovado, but did not 
extend inland beyond $600 \mathrm{~m}$ from the ocean. We hypothesized that G. quadratus might be physiologically or ecologically limited from inland habitat and predicted that this limitation would be expressed in a high density of crabs close to the ocean and a lower density of crabs farther inland. Furthermore, we expected that lower leaf litter depth and seedling density would be associated with a higher density of land crabs. Consequently, the primary objective of our research was to quantify the density of G. quadratus in Corcovado National Park along a distance gradient from the ocean. Our secondary objective was to determine the relationship between land crab density, leaf litter depth, seedling density, and substrate.

\section{MATERIALS AND METHODS}

This study was conducted at Sirena Field Station, Corcovado National Park, Osa Peninsula, Costa Rica $\left(8^{\circ} 30^{\prime} \mathrm{N}, 83^{\circ} 30^{\prime} \mathrm{W}\right)$. Vegetation in the Pacific lowland region of the Corcovado plain is tropical wet rainforest. These areas support populations of the land crab G. quadratus de Saussure, a species synonymous with $G$. lateralis Freminville (Turkay 1973). This species has a general distribution along the Atlantic and Pacific coasts of tropical North, Central and South America (Burggren and McMahon 1988). Within Costa Rica, surveys have found populations of G. quadratus along the northern Pacific coast at Bahía de Culebra, Cabo Blanco, Puntarenas, Boca de Barranca, Caldera, and Pigres and along the southern Pacific coast at Golfito (Bright 1966). Populations have also been well described at Sirena Field Station (Sherman 1997, 2002, 2003).

We carried out field surveys from 8-10 January 2002 at a study area adjacent to the Rio Sirena Trail. Density of G. quadratus was estimated by counting the number of active burrows, an index commonly used to assess land crab population size because these animals construct deep subterranean caves with only one opening (Kellman and Delfosse 1993, Sherman 1997). Burrows were surveyed along a single $420 \mathrm{~m}$ transect placed perpendicular to the shoreline. At $15 \mathrm{~m}$ intervals along the transect, we randomly placed two $5 \mathrm{~m}^{2}$ sampling quadrats located within $20 \mathrm{~m}$ of one another. Within each quadrat, we counted number of land crab burrows, dicot tree saplings $<1 \mathrm{~m}$ and, when present, land bromeliads (Achmea magdalenae). We also measured leaf litter depth using a ruler (measured in two replicates averaged per quadrat) and type of substrate (sand= large particles and low water content; clay $=$ fine particles with high water content). The substrate classes had a patchy distribution throughout the study area but were always distinguishable.

Data were analyzed using general linear models and correlation procedures in SAS (SAS Institute 1990), with quadrat pairs averaged to avoid pseudoreplication. Linear regressions were run on numbers of land crab burrows, tree saplings, land bromeliads, and leaf litter depth. A Mann-Whitney U test was used to assess burrow density in different substrate types.

\section{RESULTS}

Average density of G. quadratus burrows ranged from 0 to $5.3 \mathrm{~m}^{-2}$, which is consistent with patterns described by (Sherman 1997). Burrow density declined and became less variable as distance from the ocean increased $(\mathrm{df}=$ $27, r^{2}=0.313, p<0.001$; Fig. 1A). Scatter along the axes was high but burrow density was more variable close to the ocean. Two secondary peaks in density at $150 \mathrm{~m}$ and $230 \mathrm{~m}$ inland correspond with areas of sand substrate. We found that areas with higher burrow density had lower leaf litter depth $\left(\mathrm{df}=27, \mathrm{r}^{2}=0.266\right.$, $\mathrm{p}<0.001$; Fig. 1B). The number of saplings decreased with increased burrow density $(\mathrm{df}=$ $27, \mathrm{r}^{2}=0.090, \mathrm{p}=0.022$; data not shown). Areas with land bromeliads tended to support few other plant species, and there was no significant correlation between number of burrows and number of land bromeliads $\left(\mathrm{df}=27, \mathrm{r}^{2}=0.022\right.$, $\mathrm{p}=0.389$; data not shown). Crab burrows rarely occurred in the clay substrate, while sample 

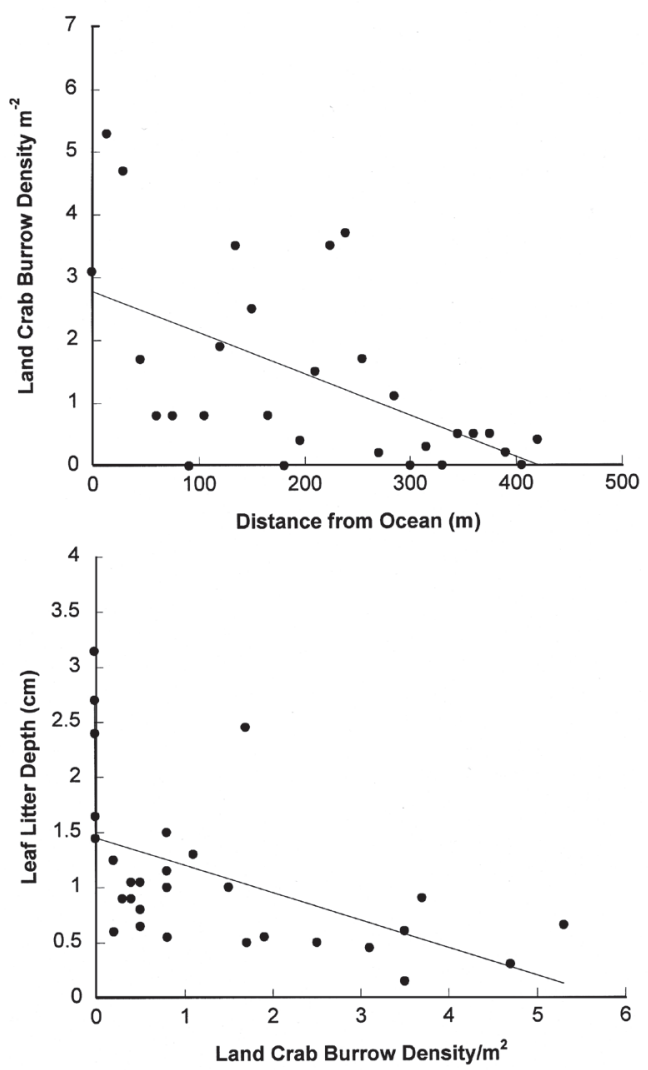

Fig. 1. (A) Number of G. quadratus burrows found per $1 \mathrm{~m}^{2}$ along a gradient of distance from the ocean and (B) depth of leaf litter in areas with differing numbers of $G$. quadratus burrows.

quadrats in the sand substrate had many more crab burrows $(\mathrm{U}=9.5, \mathrm{p}=0.035$; Fig. 2). We also noted that burrow location was often associated with tree root systems.

\section{DISCUSSION}

While relatively little is known about the specific factors that affect G. quadratus density in coastal tropical rainforests, the patterns we observed suggest that there are distribution limits in this species. The land crab G. quadratus could be restricted from inland habitats through abiotic or biotic conditions, as are other terrestrial crustaceans (Friend and Richardson 1986, Richardson et al. 1991, Richardson 1993,

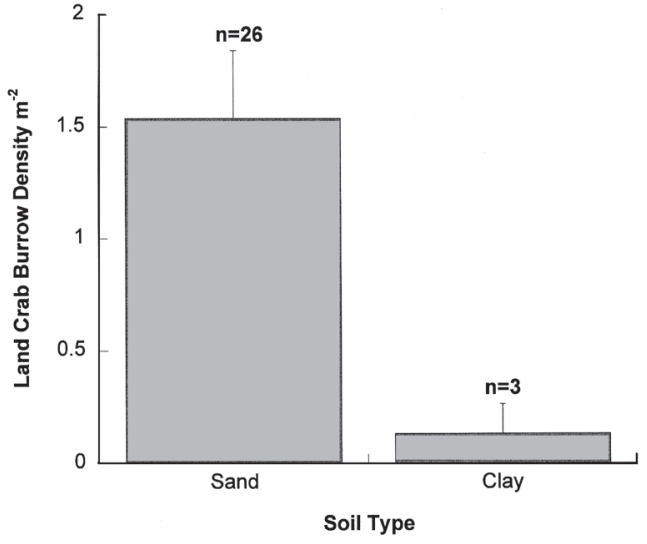

Fig. 2. Mean number ( $\pm 1 \mathrm{SE})$ of G. quadratus burrows in two substrate types.

Richardson and Swain 2000, Richardson et al. 2001). Of the many possible abiotic factors limiting inland distribution of G. quadratus, the most likely include water availability, ions, or substrate properties. Physiological constraints on water or ion availability could result in the limitation of these land crabs to coastal regions. However, research has demonstrated that land crabs have the ability to precisely regulate both water and ion loss (Wolcott 1992, Greenaway 1994). Bliss (1963) suggested that G. lateralis is dependent on air moisture and proposed this as an explanation for their distribution. Furthermore, the terrestrial crustaceans in the Talitridae family are limited by ions available through salt spray from the ocean (Richardson 1993, Morrit and Richardson 1999). While studies have demonstrated that sodium and chloride are not limiting to G. lateralis, there is the possibility that some other ions in salt spray limit their distribution (Wolcott and Wolcott 1988).

Soil preferences of G. quadratus have not been studied extensively, and this warrants further research. We found a significant difference in burrow number between the two common substrate types found in our study area. Crabs avoided digging burrows in the damp clay substrates, perhaps due to structural instability, difficulty in digging in the substrate type, or a tendency for the burrows to become waterlogged. Water content and soil types could 
influence land crab burrow construction and distribution in the forest. Furthermore, plant communities within the forest could differentially affect soil water content. Crabs might therefore be limited from inland areas because suitable substrate is unavailable.

Biotic factors, such as competition, predation, or dispersal ability, might limit land crab distribution. Land crabs could be limited from inland forests by the presence of a competitor for space or other resources. A restriction on distribution by competition or predation seems unlikely, however, because the transition from the area inhabited by crabs to the area without crabs is quite abrupt (Sherman 1997, 2002, 2003). It is also possible that these crabs are limited by their dispersal ability. G. quadratus have pelagic larvae and migrate to the ocean for reproduction. This species could be restricted to the coastal zone by the migration distance (Wolcott and Wolcott 1982, Hicks 1985). Although little is known about how far these crabs can move during the spawning period; Sherman (1997) notes that adult crabs dominate the population beginning approximately $200 \mathrm{~m}$ from the ocean and extending inland.

There are several caveats to consider when interpreting the data reported here. Many other factors could either contribute to or account for the patterns that we find in G. quadratus distribution. First, age structure of the population could be influencing the observed distribution. Younger crabs inhabit the areas closest to the ocean (Sherman 1997), and there could be a higher density of crabs in this area because there are more juveniles in the population than adults. Also, there are profound seasonal differences in land crab behavior. These data were collected during the early part of the dry season, when crabs begin a three-month period of estivation (Sherman 1997). As a result, the trends we see in leaf litter depth could reflect differences in tree community structure at different distances rather than a difference in land crab consumption rates. However, given that we saw clear patterns using only one transect at a time period when crab activity is low, it is possible that the trends are more pronounced than we describe.

Despite the limitations of this research, the results reported here suggest that the local distribution of G. quadratus is limited to a very narrow coastal zone on Osa peninsula. A considerable degree of spatial variation warrants using a high number of replicate transects extending beyond $600 \mathrm{~m}$ from the ocean. We recommend that further research on land crab distributions be carried out, particularly looking at the mechanistic details of how soil substrate influences land crab distributions. Other potentially relevant factors like competition, predation, and dispersal limitation should also be considered. Sherman $(1997,2002,2003)$ has demonstrated that G. quadratus occupies a critical ecological role at Sirena, and understanding the factors controlling the distribution of this species will help us better understand the tropical coastal rainforest ecosystems they inhabit.

\section{ACKNOWLEDGMENTS}

We thank J.M. Reed for statistical advice, C.M. Orians for support in the field and the Draupner Ring Foundation, Tufts Institute for the Environment and Tufts University for funding.

\section{RESUMEN}

El cangrejo terrestre Gecarcinus quadratus es una especie "ingeniera" que controla el ciclo de nutrientes en los bosques tropicales. Los factores que regulan su distribución a lo largo de las costas no se conocen de forma definitiva. Se cuantificó la distribución del cangrejo terrestre durante la estación seca en la Estación de Campo Sirena en el Parque Nacional de Corcovado, Costa Rica, y se encontró que la densidad de galerías del cangrejo terrestre disminuye al aumentar la distancia al océano. La profundidad de la hojarasca y la densidad de plántulas de especies arbóreas están negativamente correlacionadas con la densidad de galerías del cangrejo terrestre. Las 
galerías aparecen fuertemente asociadas con el sustrato arenoso y la densidad de galerías es comparativamente más baja en sustratos arcillosos. Estos resultados sugieren que $G$. quadratus se encuentra en una zona costera estrecha con sustrato arenoso, y que esta distribución podría tener efectos importantes en la estructura de la comunidad vegetal.

Palabras clave: cangrejos terrestres, densidad de galerías, Gecarcinus quadratus, Gecarcinus lateralis, hojarasca, Parque Nacional de Corcovado.

\section{REFERENCES}

Bliss, D.E. 1963. The pericardial sacs of terrestrial Brachyura, p. 59-78. In H.B. Whittington \& W.D.I. Rolfe (eds.). Phylogeny and evolution of Crustacea. Museum of Comparative Zoology, Harvard University, Cambridge, Massachussetts, USA.

Bliss, D.E. 1968. Transition from water to land in decapod crustaceans. Am. Zool. 8: 355-392.

Bright, D.R. 1966. The land crabs of Costa Rica. Rev. Biol. Trop. 14: 183-203.

Bright, D.R. \& C.L. Hogue. 1972. A synopsis of the burrowing land crabs of the world and list of their arthropod symbionts and burrow associates. Natur. Hist. Mus. Los Angeles County Cont. Sci. 220: 1-58.

Burggren, W.W. \& B.R. McMahon. 1988. Biology of the land crabs. Cambridge, Cambridge, England. 479 p.

Friend, J.A. \& A.M.M. Richardson. 1986. Biology of terrestrial amphipods. Annu. Rev. Entomol. 31: 25-48.

García-Franco, J.G., V. Rico-Gray \& O. Zayas. 1991. Seed and seedling predation of Bromelia pinguin L. by the red land crab Gecarcinus lateralis Frem. in Veracruz, Mexico. Biotropica 23: 96-97.

Green, P.T., D.J. O’Dowd \& P.S. Lake. 1997. Control of seedling recruitment by land crabs in rain forest on a remote oceanic island. Ecology 78: 2474-2486.

Green,P.T., P.S. Lake \& D.J. O’Dowd. 1999. Monopolization of litter processing by a dominant land crab on a tropical oceanic island. Oecologia 119: 435-444.

Greenaway, P. 1994. Salt and water balance in field populations of the terrestrial crab Gecarcoidea natalis. J. Crustac. Biol. 14: 438-453.
Hicks, J.W. 1985. The breeding behaviours and migrations of the terrestrial crab Gecarcoidea natalis (Decapoda: Brachyura). Aust. J. Zool. 33: 127-142.

Jiménez, C., A. Ortega-Rubio, S. Álvarez-Cárdenas \& G. Arnaud. 1994. Ecological aspects of the land crab Gecarcinus planatus (Decapoda: Gecardinidae) in Socorro Island, Mexico. Biol. Conserv. 69: 9-13.

Jones, C.G., J.H. Lawton \& M. Shachak. 1994. Organisms as ecosystem engineers. Oikos 69: 373-386.

Kellman, M. \& B. Delfosse. 1993. Effect of the red land crab (Gecarcinus lateralis) on leaf litter in a tropical dry forest in Veracruz, Mexico. J. Trop. Ecol. 9: 55-65.

Morrit, D. \& A.M.M. Richardson. 1999. Osmoregulation and evolutionary patterns in coastal terrestrial amphipods (Talitridae). J. Crustac. Biol. 20: 67-74.

O’Dowd, D.J. \& P.S. Lake. 1991. Red crabs in rain forest, Christmas Island: removal and rate of fruits and seeds. J. Trop. Ecol. 7: 113-122.

Richardson, A.M.M. 1993. The distribution of coastal group landhoppers (Crustacea: Amphipoda: Talitridae) related to sea spray at Cox Bight, Tasmania. Pap. Proc. R. Soc. Tasman. 127: 55-60.

Richardson, A.M.M. \& R. Swain. 2000. Terrestrial evolution in Crustacea: The talitrid amphipod model. Crustac. Issues 12: 807-816.

Richardson, A.M.M., R. Swain \& S.J. Smith. 1991. Local distributions of sandhoppers and landhoppers (Crustacea: Amphipoda: Talitridae) in the coastal zone of western Tasmania. Hydrobiologia 223: 127 140.

Richardson, A.M.M., R. Swain \& C.J. McCoull. 2001. Salt spray limits the inland penetration of a coastally restricted invertebrate: a field experiment using landhoppers (Crustacea: Amphipoda: Talitridae). Funct. Ecol. 15: 435-442.

SAS Institute. 1990. SAS User's Guide, Version 6. Fourth Edition. SAS Institute, Raleigh, North Carolina, USA.

Sherman, P.M. 1997. Direct and indirect effects of the land crab Gecarcinus quadratus (Gercarcinidae) on seedling density, organic carbon distributions and rooting profiles in Corcovado National Park, Costa Rica. Ph.D. Thesis, University of Michigan, Michigan, USA. 194 p. 
Sherman, P.M. 2002. Effects of land crabs on seedling densities and distributions in a mainland neotropical forest. J. Trop. Ecol. 18: 67-89.

Sherman, P.M. 2003. Effects of land crabs on leaf litter distributions and accumulations in a mainland tropical rainforest. Biotropica 35: 365-374.

Turkay, M. 1973. Bemerkungen zu einigen Landkrabben (Crustacea, Decapoda). Bull. Mus. Nat. Hist. Paris 142: 969-980.
Wolcott, T.G. 1992. Water and solute balance in the transition to land. Am. Zool. 32: 428-437.

Wolcott, T.G. \& D.L. Wolcott. 1982. Larval loss and spawning behavior in the land crab Gecarcinus lateralis (Fréminville). J. Crustac. Biol. 2: 477-485.

Wolcott, T.G. \& D.L. Wolcott. 1988. Availability of salts is not a limiting factor for the land crab Gecarcinus lateralis (Fréminville). J. Exp. Mar. Biol. Ecol. 120: 199-219. 